\title{
A globális népességnövekedés mozgatórugói és a várható jövőbeli folyamatok ${ }^{1}$
}

\author{
Drivers of the Global Population Growth and Expected \\ Future Processes
}

Tanulmányomban globális népesedési kérdésekkel foglalkozom a teljes termékenységi arányszám, illetve a reprodukciós szinthez tartozó fertilitási ráta segítségével. A tanulmányban 2100-ig számítom ki a világ országaira a reprodukciós szinthez tartozó fertilitási rátát. Az elemzés alapján a reprodukciós szinthez tartozó fertilitási ráta értéke és szórása az elmúlt évtizedekben jelentösen csökkent, azonban a teljes termékenységi arányszám még nagyobb mértékü csökkenése miatt a világ ceteris paribus már csak alig-alig reprodukálja újra önmagát, a gyermekvállalási hajlandóság a legtöbb országban a reprodukciós szint alá esett. Évszázadunkban alapvetöen már csak az idősebb korúak lélekszámának növekedése fogja meghatározni a globális népességnövekedést, így a világ népességnövekedési üteme még tovább lassulhat, a túlnépesedés helyett a társadalmakban egyre inkább az elöregedés válhat globális problémává.

JEL-klasszifikáció: J11, J13, N30

Kulcsszavak: népességnövekedés, teljes termékenységi arányszám, reproduktivitás, reprodukciós szinthez tartozó fertilitási ráta

In my study, I examine global population issues using the total fertility rate and the replacement fertility rate. In my paper, I calculate the replacement level fertility rate for the countries of the world by 2100. According to the analysis, the value and standard deviation of the replacement level fertility rate have decreased significantly

Drabancz Áron a Budapesti Corvinus Egyetem Általános és Kvantitatív Közgazdaságtan Doktori Iskola doktori hallgatója. E-mail: aron.drabancz@gmail.com

A kutatást az EFOP-3.6.2-16-2017-00017 azonosítószámú „Fenntartható, intelligens és befogadó regionális és városi modellek” című projekt támogatta. A projekt az Európai Unió támogatásával, az Európai Szociális Alap és Magyarország költségvetése társfinanszírozásában valósul meg. A kutatást emellett az Innovációs és Technológiai Minisztérium, valamint a Nemzeti Kutatási, Fejlesztési és Innovációs Hivatal Kooperatív Doktori Programja is támogatta. 
in recent decades, however, due to an even greater decline in the total fertility rate, the world ceteris paribus is barely reproducing itself, the propensity to have children have fallen below the reproductive level in most countries. In our century, basically only an increase in the population of older people will determine global population growth, thus, the world's population growth rate may slow down even further, instead of overpopulation, aging could become the biggest demographic global problem.

JEL classification: $\mathrm{J} 11, \mathrm{~J} 13, \mathrm{~N} 30$

Keywords: population growth, total fertility rate, reproductivity, replacementlevel fertility

\section{Bevezetés}

Az elmúlt évtizedekben a túlnépesedés egyre inkább központi kérdéssé vált, részben mert a probléma szorosan összefügg a fenntarthatósággal is. A gyors népességnövekedés amellett, hogy rontja egy ország versenyképességét és növekedési lehetőségeit, ${ }^{2}$ még nehezíti is a klímaváltozás elleni harcot, illetve a szűkös természeti erőforrások (például olaj, ivóvíz, ércek stb.) iránt is nagyobb versenyt indukál. Emellett az erdőirtások növekvő számát, a jólétre és éghajlatra gyakorolt negatív hatást, a csökkenő élelmiszer-biztonságot, illetve biodiverzitást hozzák még általában kapcsolatba a túlnépesedéssel. ${ }^{3}$ Növekvő lélekszámú országoknak kifejezetten nehéz elérni, hogy a társadalom ökológiai lábnyoma alatta maradjon a rendelkezésre álló biokapacitásnak, a klímacélokkal összhangban. Egyes elemzések igazán sötét képet festenek a jövőről: a túlnépesedés miatt az alultápláltak számának gyorsuló növekedését, illetve a kimerülő természeti erőforrások miatt hosszú távon a világ népességének jelentős csökkenését. ${ }^{4}$ Azonban véleményem szerint mára a világ népességalakulására a „túlnépesedés” kifejezés használata megtévesztő, hisz az évi 1\%-os népességnövekedés ellenére a világ népességnövekedésének fő oka ma már valószínűleg nem a gyermekvállalások magas száma, sokkal inkább a javuló mortalitási mutatók. A korábbi kvantitatív növekedés mára egyre inkább kvalitatív alapúvá vált, és a jövőben valószínúleg a javuló mortalitás lesz az egyetlen jelentős hajtóereje a világ népességnövekedésének. A világ a népességnövekedés kiegyensúlyozott, egyre inkább lassuló korszakába lépett, amelynek globálisan a fő hajtóereje már nem a gyermekvállalások magas számában keresendő, így a „túlnépesedés” helyett a „globális elöregedés” válhat az egyik legnagyobb kihívássá a fejlett és fejlődő gazdaságok számára is.

Tanulmányomban a fenti állítást elemzem a népesedési folyamatok vizsgálatával, illetve a teljes termékenységi arányszámon (TTA), illetve a reprodukciós szinthez tartozó fertilitási rátán (RSZTFR) keresztül. A UN 2019-es adatbázisa alapján számítom

Edward M. Crenshaw - Ansari Z. Ameen - Matthew Christenson: Population dynamics and economic development: Age-specific population growth rates and economic growth in developing countries, 1965 to 1990. American Sociological Review, 62. (1997), 6. 974-984.

3 Uniyal Shivani et alii: Human overpopulation: Impact on environment. In Megacities and Rapid Urbanization. Information Resources Management Association, 2020. 20-30.

$4 \quad$ David Pimentel: World overpopulation. Environment, Development and Sustainability, 14. (2012), 2. $151-$ 152. 
ki a reprodukciós szinthez tartozó fertilitási rátát 1950 és 2100 között, majd a kapott eredményeket a teljes termékenységi arányszám értékeivel vetem egybe. ${ }^{5}$ Továbbá megvizsgálom, hogy a gyermekvállalások nagysága miként járult hozzá a világ népességnövekedéséhez 1955 óta.

Tanulmányom következő, 2. fejezetében bemutatom a téma relevanciáját, illetve áttekintem a kapcsolódó főbb szakirodalmakat arra vonatkozóan, hogy mely hatások miatt csökkenhet a globális gyermekvállalási igény. Ezt követően a 3. fejezetben bemutatom a témához kapcsolódó fontosabb fogalmakat és a reprodukciós szinthez tartozó fertilitás számítási metódusát, majd a 4. fejezetben kutatásom főbb eredményeit ismertetem, az 5. fejezetben a téma koronavírushoz kapcsolódó friss aspektusait elemzem, a 6 . fejezetben pedig összegzem a tanulmányt, bemutatom a legfontosabb következtetéseket.

\section{2. Áttekintés}

Az elmúlt évszázadokban, a Nyugat-Európából kiinduló ipari forradalom hatására egyre több helyen ment végbe a társadalmak demográfiai átstrukturálódása. Az ipari forradalomból kiinduló változások jelentősen növelték az egyén túlélési valószínűségét, ennek hatására az átalakulásban érintett térségekben exponenciális népességnövekedés volt tapasztalható. A fejlődés térbeli terjedésével a hatás fokozatosan megjelent Kelet-Európában, Észak-Amerikában, majd elérte a fejlődő térségeket Dél-Amerikában, Ázsiában és Afrikában is. Ennek hatására a Föld népessége az elmúlt 200 évben drámai mértékben növekedett. Az 1800-as évek elején a Föld népessége még csak 1 milliárd körül alakult, ma már viszont 7,8 milliárd. ${ }^{6}$ A népességnövekedés üteme az 1960-as évekig gyorsult a világban, utána a gyorsulás mértéke csökkeni kezdett: míg az 1960-as években közel 2,1\%-os volt az éves növekedési ütem, ma már csak körülbelül évente 1\%-kal növekszik a világ népessége.

1. táblázat

A világ népességének változása

\begin{tabular}{|l|c|c|c|c|c|c|c|c|c|c|}
\hline $\begin{array}{l}\text { Népesség } \\
\text { (milliárd fö) }\end{array}$ & 1 & 2 & 3 & 4 & 5 & 6 & 7 & 8 & 9 & 10 \\
\hline Év & 1804 & 1927 & 1960 & 1974 & 1987 & 1999 & 2011 & 2023 & 2037 & 2056 \\
\hline Eltelt idö* & - & 123 & 33 & 14 & 13 & 12 & 12 & 12 & 14 & 19 \\
\hline $\begin{array}{l}\text { Átlagos éves } \\
\text { növekedési ütem }\end{array}$ & $0,5 \%$ & $1,2 \%$ & $2,1 \%$ & $1,7 \%$ & $1,5 \%$ & $1,3 \%$ & $1,1 \%$ & $0,8 \%$ & $0,6 \%$ & - \\
\hline
\end{tabular}

*Eltelt idő, míg a világ népessége újabb 1 milliárd fővel emelkedik. Forrás: a szerző szerkesztése Worldometer: World Population by Year. 2020a és Worldometer: World Population Projections. 2020b adatai alapján. ${ }^{7}$

UN: World Population Prospects 2019.

Worldometer (2020a) i. m.

Worldometer (2020a) i. m.; Worldometer (2020b) i. m. 
Három tényező befolyásolhatja demográfiai szempontból egy ország népességének alakulását: a gyermekvállalások száma, a mortalitási adatok, illetve a migrációs folyamatok. Mivel globálisan a migrációs egyenleg zéró, így elemzésemben ezzel nem foglalkozom. Napjainkban a kohorszok teljes spektrumán érzékelhető javuló mortalitási mutatók népességnövelő hatása nehezebben visszafejthető, mint a gyermekvállalás nagysága, így elemzésemet a teljes termékenységi arányszám irányából kezdem. A teljes termékenységi arányszám megadja, hogy egy nő élete folyamán átlagosan hány gyermeknek adna életet, ha az adott év termékenységi adatai állandósulnának. ${ }^{8}$ A mutató az 1950 -es és 1960-as években, globális átlagban még 5 körül alakult, mára azonban megfeleződött és 2,5 alatt található. Magyarországon a mutató 1980 óta nem éri el kettőt, és várhatóan az egész 21. évszázadban jelentősen a reprodukciós szint alatt fog maradni a UN 2019-es adatai alapján. A magyar népesség jövőbeli alakulását modellező elemzések közül még a legoptimistább szcenáriókban sem éri el a fertilitási ráta értéke a reprodukcióhoz szükséges szintet. ${ }^{9}$ A ráta globális csökkenésének fő oka a gazdasági fejlődés, amelynek a termékenységgel való negatív kapcsolata a társadalomtudományok egyik legalapvetőbb empirikus szabályszerűsége. A gazdasági fejlettséggel kapcsolatban álló változók, mint a családtervezési eljárások, illetve a fogamzásgátlási módszerek ismerete szintén fontos meghatározója a teljes termékenységi arányszám változásának. ${ }^{10}$ Sok nagyon fejlett gazdaságban a fertilitás lefelé mutató trendje továbbra is visszafordíthatatlannak tűnik, bár a szakirodalom szerint a fertilitás és a fejlettség U-alakú, tehát bizonyos fejlettségi szint után a fertilitási számok javulása figyelhető meg. ${ }^{11} \mathrm{~A}$ II. világháborút követően a fejlett világban a gyermekvállalási hajlandóság jelentősen átalakult: a legtöbb országban a teljes termékenységi arányszám a reprodukciós szint alá esett, amely példátlan volt addig a történelem során. ${ }^{12} \mathrm{Az}$ okok között általában megemlítik az együttélés formájának megváltozását (házasságok számának csökkenése, élettársi kapcsolat előretörése, válások számának növekedése), ${ }^{13}$ a nők fokozódó gazdasági

KSH Népességtudományi Kutatóintézet: Teljes termékenységi arányszám szócikk.

Branislav Bleha et alii: Population projections for Hungary and Slovakia at national, regional and local levels. Population projections developed within the project 'SEEMIG Managing Migration and Its Effects - Transnational Actions Towards Evidence Based Strategies, 2014.; Obádovics Csilla: A népesség szerkezete és jövője. In Monostori Judit - Őri Péter - Spéder Zsolt (szerk.): Demográfiai Portré 2018. Budapest, KSH Népességtudományi Kutatóintézet, 2018. 271-294.

10 Charles F. Westoff: Reproductive Intentions and Fertility Rates. International Family Planning Perspectives, 16. (1990), 3.; Ong Tsui - Amy Bogue - Donald J. Bogue: Declining world fertility: trends, causes, implications. Population Bulletin, 33. (1978), 4. 2-56.

11 Mikko Myrskylä - Hans-Peter Kohler - Francesco C. Billari: Advances in development reverse fertility declines. Nature, 460. (2009), 7256. 741-743.

12 Kingsley Davis: Low fertility in evolutionary perspective. Population and Development Review, 12. (1986), 48-65.

13 Nick Buck - Jacqueline Scott: Household and family change. In Nick Buck et alii: Changing Households: The British Household Panel Survey 1990-1992. University of Essex, ESRC Centre on Micro-Social Change, 1994. 
függetlenedését ${ }^{14}$ és munkaerőpiaci aktivitásának erősödését, ${ }^{15}$ az egyedül élő személyek elfogadottságának növekedését. ${ }^{16}$

Továbbá a gyermek is egyre fontosabbá vált az évszázadok során: a gyermekhalálozások visszaszorulásával a gyermek „felértékelődött”, erősödött az irányukba mutatott érzelmi kötődés és az érdek is, hogy megfelelő képzést kapjanak. ${ }^{17} \mathrm{~A}$ társadalom átalakulásával, a növekvő egészségügyi és oktatási költségek miatt a gyermekek felnevelése egyre többe került, és a gyermekek első munkavállalási időpontjának kitolódásával ma már a szülőknek egyre tovább és egyre több pénzzel kell támogatni gyermekeiket, ami az alacsony vagy nulla fertilitást egyre racionálisabbá teheti. A jólét növekedésével a világ összes országában egyre növekednek - tisztán közgazdaságtani megközelítés alapján - a gyermekvállaláshoz kapcsolódó költségek, így a gyermekvállalási hajlandóság visszaszorulása a jövőben is megmaradhat. A UN 2019-es előrejelzései alapján ez leginkább a fejletlenebb országokban érvényesülhet. Itt a jövőben szinte minden országban jelentősen csökkenhet a teljes termékenységi arányszám, míg a fejlett országokban - a jólét és a termékenység feltehetőleg U alakú kapcsolata miatt - a szervezet enyhe növekedést valószínűsít a megszülető gyermekek számára vonatkozóan.

\section{Reprodukciós szinthez tartozó fertilitási ráta}

A fejezet célja röviden bemutatni a reprodukciós szinthez tartozó fertilitási ráta számítási metódusát, és a mutató teljes termékenységi arányszámmal való kapcsolatát. A mutató megadja, hogy egy adott országban ceteris paribus egy nőnek élete folyamán átlagosan hány gyermeknek kellene életet adnia, hogy a társadalom „újratermelje” önmagát, a népesség ne változzon. A mutató így a legtöbb országban egy 2-höz közeli értéket vesz fel, a pontos értékét a nemek születéskori aránya, illetve a mortalitási mutatók határozzák meg. Egy háború, járványok vagy éhínségek sújtotta fejlődő országban a lakók túlélési esélyei olyan rosszul is alakulhatnak, hogy a nőknek átlagosan akár 3-nál is több gyermeket kell vállalniuk a társadalom újratermelődéséhez. Továbbá a legtöbb országban a nemek születéskori arányában a férfiak nagyobb súlyt képviselnek, így a nőknek 2-nél kicsivel több gyermeket kell vállalniuk ahhoz, hogy megfelelő számú jövőbeli anya születhessen. Egyes térségekben kulturális tradíciók miatt a fiúgyermek sokkal értékesebb, mint a lány (például Ázsia, Afrika egyes országaiban), itt a világátlagnál is több

Andrew J. Cherlin: Marriage, Divorce, Remarriage. Cambridge, Harvard University Press, 1992.

Rachel A. Rosenfeld - Gunn E. Birkelund: Women's part-time work: A cross-national comparison. European Sociological Review, 11. (1995), 2. 111-134.

16 Frank F. Furstenberg: Family change and the welfare of children: What do we know and what can we do about? In Karen Oppenheim Mason - An-Magritt Jensen (szerk.): Gender and Family Change in Industrialised Countries. Oxford, Clarendon Press, 1995. 245-257.

17 Lawrence Stone: The Family, Sex and Marriage in England 1500-1800. New York, Harper and Row, 1977; Jürgen Schlumbohm: Traditional collectivity and modern individuality: Some questions and suggestions for the historical study of socialization: The examples of the German lower and upper bourgeoisie around 1800. Social History, 5. (1980), 1. 71-103.

Európai Tükör 2020/4. 
fiúgyermek jut egy lánygyermekre. Kínában az egygyermekes politika ezt még tovább torzította, ${ }^{18}$ az országban a reprodukciós szinthez tartozó fertilitási ráta jóval magasabb, mint ami a mortalitási adatokból következne.

$\mathrm{Az}$ alacsony mortalitási mutatókkal rendelkező fejlett térségekben általában 2,1-es teljes termékenységi arányszámot szoktak kritikusnak feltételezni, amelyet el kell érni a társadalomnak ahhoz, hogy a népesség hosszú távon ne csökkenjen. ${ }^{19} \mathrm{~A}$ ráta sokszor téves értelmezésekor ez a szám kerül előtérbe: az ez alatti teljes termékenységi arányszámok negatív jelenségként jelennek meg, ezen országok népességére elöregedés és a népesség fogyása jellemző, miközben javuló mortalitási adatok mellett a reprodukciós szint alatti fertilitási ráta esetén is növekedhet egy ország népessége akár nulla nettó migrációs ráta mellett is. A 2,1 fölötti teljes termékenységi arányszám értékek esetén szintén negatív jelzők, a túlzó népességnövekedés, az ország túlnépesedése kerül előtérbe. Így a világon 2,1-es teljes termékenységi arányszám vált az „áhított céllá”; ${ }^{20}$ Magyarország demográfiai célkitűzéseiben is ez a szám köszön vissza. ${ }^{21}$ Azonban ezen érték puszta alkalmazása a világ országaira nézve igencsak leegyszerúsítő, hisz a mutató értéke jelentős szórást mutat, és számos országban jelentősen nagyobb a 2,1-es értéknél. ${ }^{22}$

Célom a kutatással jobban megérteni a reprodukciós szinthez tartozó fertilitási ráta működési mechanizmusát. A reprodukciós szinthez tartozó fertilitási ráta meghatározásához a Világbank és a UN 2019-es adatbázisait használtam fel, amelyek éves vagy ötéves intervallumban tartalmazzák a kohorszok szerinti népesség- és halálozási számadatokat, a nemek születéskori arányát, az egyes kohorszok halálozási számait és a várható élettartamot 1950-től 2100-ig. ${ }^{23} \mathrm{Az}$ elemzésben részt vevő 195 ország a világ össznépességének a 99,95\%-át fedi le. Három ország adatsora nem volt teljes, azonban az elemzésben mégis szerepeltek, a reprodukciós szinthez tartozó fertilitási rátájukat a hiányzó évekre más országok értékei alapján becsültem. ${ }^{24} \mathrm{~A}$ reprodukciós szinthez tartozó fertilitási ráta számításakor a női nem van fókuszban, cél annak a fertilitási rátának a meghatározása, hogy az elkövetkező generációban élő szülőképes korú nők lélekszáma megegyezzen a jelenlegi generációban élő szülőképes korú nők lélekszámával. Ezt tovább folytatva az elkövetkező generáció hasonló problémával szembesül, ám ha ugyancsak a reprodukciós szintnek megfelelő gyermeket szülnek a nők, akkor a majd két generációval később élő szülőképes korú nők lélekszáma éppen meg fog egyezni a most

18 Hongbin Li - Junjian Yi - Junsen Zhang: Estimating the effect of the one-child policy on the sex ratio imbalance in China: Identification based on the difference-in-differences. Demography, 48. (2011), 4. 1535-1557.

19 Thomas J. Espenshade - Juan C. Guzman - Charles F. Westoff: The surprising global variation in replacement fertility. Population Research and Policy Review, 22. (2003), 5-6. 575-583. Stuart Gietel-Basten - Sergei Scherbov: Exploring the 'True Value' of Replacement Rate Fertility. Population Research and Policy Review, 39. (2019), 763-772.

21 Vö.: Orbán Viktor beszéde a Magyar Diaszpóra Tanács VIII. ülésén.

22 Gietel-Basten - Scherbov (2019) i. m.; Espenshade-Guzman-Westoff (2003) i. m.

$23 \quad$ UN (2019) i. m.; Világbank: 2019.

24 Palesztina, Szerbia és Tajvan esetében voltak hiányos adatok, amelyeket a szükséges helyen Szíria, Montenegró, valamint Makaó értékeivel helyettesítettem. 
szülőképes korban lévő nők lélekszámával. Amennyiben az 1000 megszülető gyermekre jutó lányok száma érdemben nem változik az elemzés során, a reprodukciós szint teljesülésekor a ráta értéke a társadalom teljes reprodukcióját is mutatja. A mutató becsléséhez az 1000 megszülető gyermekre jutó lányok száma, illetve a női nem szülőképes korig fennálló mortalitási mutatói szükségesek. Hipotetikus példaként, ha 1000 megszülető gyermekre 480 lány jutott, és a szülőképes kort 99,2\%-uk éli meg, akkor 2,1 gyermeket kell átlagosan szülnie egy anyának. Ekkor ugyanis 1000 anya átlagosan 1008 lánygyermeknek ad életet (2100 gyermek 48\%-a), amelyek közül 1000 lány (1008 lánygyermek $99,2 \%-a)$ el is éri a szülőképes kort. A reprodukciós szinthez tartozó fertilitási ráta így elemzésemben a Sardon-féle közelítés szerint számolódik, ${ }^{25}$ a szülőképes kor eléréséhez tartozó valószínűség, illetve a megszülető gyermekekre jutó lányok hányadának aránya () értékek alapján az alábbi képlet szerint:

$$
\operatorname{RSZTFR}_{t}=\frac{1}{\left(\sum_{t=1}^{6} p_{5 t^{*}} S R_{t}\right)}(1)
$$

ahol az adott évi halálozási és kohorszszám alapján számítódott az ötévenkénti korosztályi mortalitás (), amelyek szorzata a 30 éves kor elérésének valószínűségét adja. A számítás megkönnyítése miatt minden egyes nő 30 éves korban vállalja gyermekeit. $\mathrm{Az}$ anya életkora a gyermek megszületésekor változóval adathiány miatt nem számoltam, azonban 15 és 40 éves kor között nagyon kevés nő hal meg, így ez valószínűleg érdemben nem befolyásolja az eredményeket.

\section{Eredmények}

A globális átlagos reprodukciós szinthez tartozó fertilitási ráta 1950-ben még közel 3-as értéket vett fel, tehát közel 3 gyermeket kellett szülni egy nőnek ahhoz, hogy ceteris paribus egy ország népessége ne csökkenjen. A ráta napjainkig jelentősen csökkent $(2,19)$, további csökkenés az elméleti alsó határ miatt már nem lehetséges, ezt jól mutatja, hogy a várakozások szerint 2040-ben is csak 0,05-el lesz alacsonyabb az érték, mint jelenleg. A reprodukciós szinthez tartozó fertilitási ráta terjedelme is jelentősen csökkent az elmúlt évtizedekben (lásd 2. táblázat). Amíg 1950-ben az országok háromnegyedében az érték a 2,43-at is meghaladta, addig mára az országok 75\%-ában 2 és 2,2 között alakul a ráta értéke. Az értékek kezdeti $63,7 \%$-os szórása 12\%-ra csökkent, amely a jövőben még tovább mérséklődhet. Az interkvartilis terjedelem egyre inkább összeszűkült: 1950-ben még közel 0,99-et kitevő érték napjainkra 0,12-re csökkent, a világ országainak nagy hányadában a reprodukciós szinthez tartozó fertilitási ráta nagyon hasonlóan alakul. (A reprodukciós szinthez tartozó fertilitási ráta hisztogramjait 1950-re, 1980-ra, 2015-re és 2040-re vonatkozóan lásd a melléklet A.1. ábráján.)

$25 \quad$ Steve Smallwood - Jessica Chamberlain: Replacement fertility, what has it been and what does it mean? Population Trends, (2005), 119. 18. 
2. táblázat

A reprodukciós szinthez tartozó fertilitási ráta változása

\begin{tabular}{|c|c|c|c|c|}
\hline & $\mathbf{1 9 5 0}$ & $\mathbf{1 9 8 0}$ & $\mathbf{2 0 1 5}$ & $\mathbf{2 0 4 0}$ \\
\hline Átlag* & 2,99 & 2,38 & 2,19 & 2,14 \\
\hline Medián & 2,82 & 2,25 & 2,11 & 2,09 \\
\hline Minimum & 2,12 & 2,08 & 2,06 & 2,05 \\
\hline Maximum & 4,87 & 3,51 & 2,64 & 2,37 \\
\hline Alsó kvartilis & 2,43 & 2,13 & 2,08 & 2,07 \\
\hline Felső kvartilis & 3,42 & 2,58 & 2,2 & 2,12 \\
\hline Szórás & $63,67 \%$ & $35,29 \%$ & $12 \%$ & $5,8 \%$ \\
\hline
\end{tabular}

*Népességszámmal súlyozva.

Forrás: a szerző számítása a UN (2019) i. m. adatai alapján, 2015 és 2015-2020-as adatokkal

Az egyes tragikus történelmi események jól megfigyelhetők a reprodukciós szinthez tartozó fertilitási ráta alakulásában. A kambodzsai (1968-1975), a Sierra Leone-i (1991-2002), a ruandai (1990-1994) vagy a szíriai (2011-) polgárháborúk mortalitásnövelő hatásai jól kimutathatók, a vizsgált időszakokban az egyes országok reprodukciós szinthez tartozó fertilitási rátája jelentős mértékben megugrott. Az 1980-as évek háborúja és éhínsége Etiópiában, az 1990-es évek HIV-/AIDS-járványa Dél-Afrikában vagy a Kínában az 1990-es évektől egyre inkább megfigyelhető nemek születéskori arányának torzulása mind többé-kevésbé megfigyelhetők a becsült adatokon. ${ }^{26}$

A reprodukciós szinthez tartozó fertilitás az 1970-1980-as évekig csökkent jelentősebb mértékben, azóta a viszonylag „jó” mortalitási mutatók már nem tudtak érdemben csökkenni (lásd 2. táblázat és 1. ábra). Ezt jól alátámasztja az öt éven aluliak halálozási aránya, amely relatíve magas értéke miatt a legfontosabb meghatározója a reprodukciós szinthez tartozó fertilitási rátának: 1950-55-ben még 1000 megszülető gyermekből 213 nem élte meg az 5 éves kort, 1980-85-re 109-re, 2010-2015-re pedig 46-ra csökkent ez az érték. Relatív értelemben a csökkenés mértéke hasonló volt (49\% és 59\%), azonban abszolút értelemben 1950 és 1980 között 100 fővel nőhetett a túlélő gyermekek száma, addig 1980 és 2010 között már csak 63-mal. A javuló mutatók miatt a jövőben a ráta hasonló érdemi csökkenésen már nem tud keresztülmenni (elméleti maximum a csökkenésre 46 fő), így a reprodukciós szinthez tartozó fertilitási ráta csökkenése korlátozott. A teljes termékenységi arányszám az 1970-es évekig magasan alakult (5), jóval meghaladta a reprodukciós szinthez tartozó mutató értékét $(2,5)$, amely hozzájárulhatott a világon tapasztalt eddigi leggyorsabb népességnövekedéshez. Azonban azóta a teljes termékenységi arányszám gyorsan csökken, és ma már alig magasabb $(2,45)$, mint a reprodukciós szinthez tartozó fertilitási ráta $(2,19)$.

26 Vö.: Gietel-Basten - Scherbov (2019) i. m. 


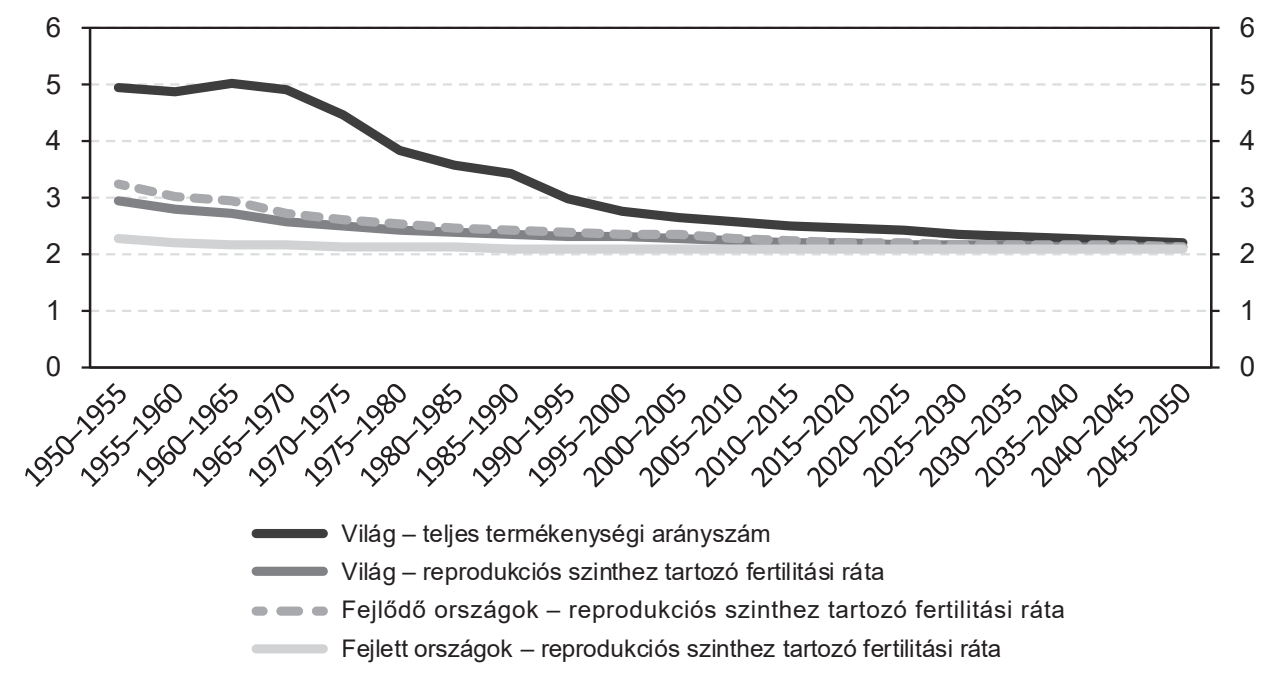

1. ábra

A teljes termékenységi arányszám és a reprodukciós szinthez tartozó fertilitási ráta változása 1950-töl 2050-ig

Forrás: a szerző számítása UN (2019) i. m. és Világbank (2019) i. m. adatai alapján

A jövőben a globális népességnövekedést tehát már nem a születendő gyermekek magas száma fogja meghatározni, sokkal inkább a javuló mortalitási adatok. Ezt jól illusztrálja a várható élettartam változása is: az elkövetkező években évtizedenként a várható élettartam 2 évvel növekedhet globálisan. A túlnépesedés és a magas gyermekvállalási hajlandóság természetesen még számos országban kihívás. Összesen 33 olyan ország (ebből 30 ország a szubszaharai Afrikában) van, ahol a teljes termékenységi arányszám, illetve a reprodukciós szinthez tartozó fertilitási ráta különbsége legalább 2, ilyen országban él ma a világ népességének 11,2\%-a. 1950-ben azonban még 131 ilyen ország volt, és a világ népességének $68 \%$-a tartozott ide.

A 3. táblázatban a világ öt legnépesebb országában a fertilitási mutatók jelenlegi alakulása látható. Kiemelendő itt India, amely talán még ma is úgy él nagyon sok ember fejében, hogy ott nagyon sok gyermeket vállalnak, és jelentős a túlnépesedés. Az országban azonban 2015-2020 óta a reprodukciós szinthez tartozó fertilitás alatta marad a teljes termékenységi arányszámnak. Vagyis Indiában a szülőképes korban élő generáció nem szül több gyermeket, mint ami a kohorszának reprodukciójához szükséges. Az ország népessége ennek ellenére még közel 40 évig növekvő pályán lesz az időskorúak relatív alacsony száma és a javuló mortalitási mutatók miatt (a várható élettartam 2020-tól 2060-ig várhatóan 70,4-ről 76,8-ra növekszik). 
3. táblázat

A világ öt legnagyobb népességü országának fertilitási jellemzői

\begin{tabular}{|c|c|c|c|c|}
\hline & $\begin{array}{c}\text { Teljes termékeny- } \\
\text { ségi arányszám }\end{array}$ & $\begin{array}{c}\text { Reprodukciós szinthez } \\
\text { tartozó fertilitási ráta }\end{array}$ & $\begin{array}{c}\text { Népesség } \\
\text { (millió fó) }\end{array}$ & $\begin{array}{c}\text { Világnépességból } \\
\text { való részesedés }\end{array}$ \\
\hline Kína & 1,69 & 2,19 & 1407 & $19,1 \%$ \\
\hline India & 2,24 & 2,24 & 1310 & $17,8 \%$ \\
\hline USA & 1,78 & 2,08 & 321 & $4,4 \%$ \\
\hline Indonézia & 2,32 & 2,13 & 258 & $3,5 \%$ \\
\hline Pakisztán & 3,55 & 2,31 & 199 & $2,7 \%$ \\
\hline
\end{tabular}

Forrás: a szerző szerkesztése a UN (2019) i. m. adatai alapján, 2015 és 2015-2020-as adatokkal

A világ népességének átstrukturálódásáról árulkodik a 2. ábra is: 1995 óta a 0-4 évesek lélekszáma 650 millió környékén stagnál, a korosztály érdemben nem járul hozzá a világ népességnövekedéséhez. Az 5-64 évesek népességnövekedéshez való hozzájárulása egyre inkább csökkenő, és 2050 után globálisan már csak a 65 évesek száma fog növekedni a világban. Ez a folyamat a demográfiai ablakon keresztül is vizsgálható, amely időintervallum kezdete, amikor a társadalmon belül a fiatalok (0-14 éves) aránya $30 \%$ alá süllyed, a vége pedig, mikor az idősek (65 évnél idősebbek) aránya a társadalmon belül meghaladja a $15 \%$-ot. ${ }^{27}$ A globális népesség jelenleg a 2000-ben induló demográfiai ablak közepén tart, várhatóan 2045 környékén haladhatja meg a 65+ évesek társadalmon belüli részaránya a 15\%-ot (lásd az A.2. táblázatot a mellékletben). Egy idei átfogó tanulmány a globális társadalom még ennél is gyorsabb demográfiai átstrukturálódását várja: a cikk szerzői elemzésük alapszcenáriójában a UN előrejelzésénél nagyobb csökkenést várnak globálisan a teljes termékenységi arányszám értékében, így a világ népessége már 2064-ben elérheti a csúcsát és onnantól enyhén csökkenő pályára áll. ${ }^{28}$

UN (2019) i. m.

Stein E. Vollset et alii: Fertility, mortality, migration, and population scenarios for 195 countries and territories from 2017 to 2100: a forecasting analysis for the Global Burden of Disease Study. The Lancet, 396. (2020), 10258. 1285-1306. 


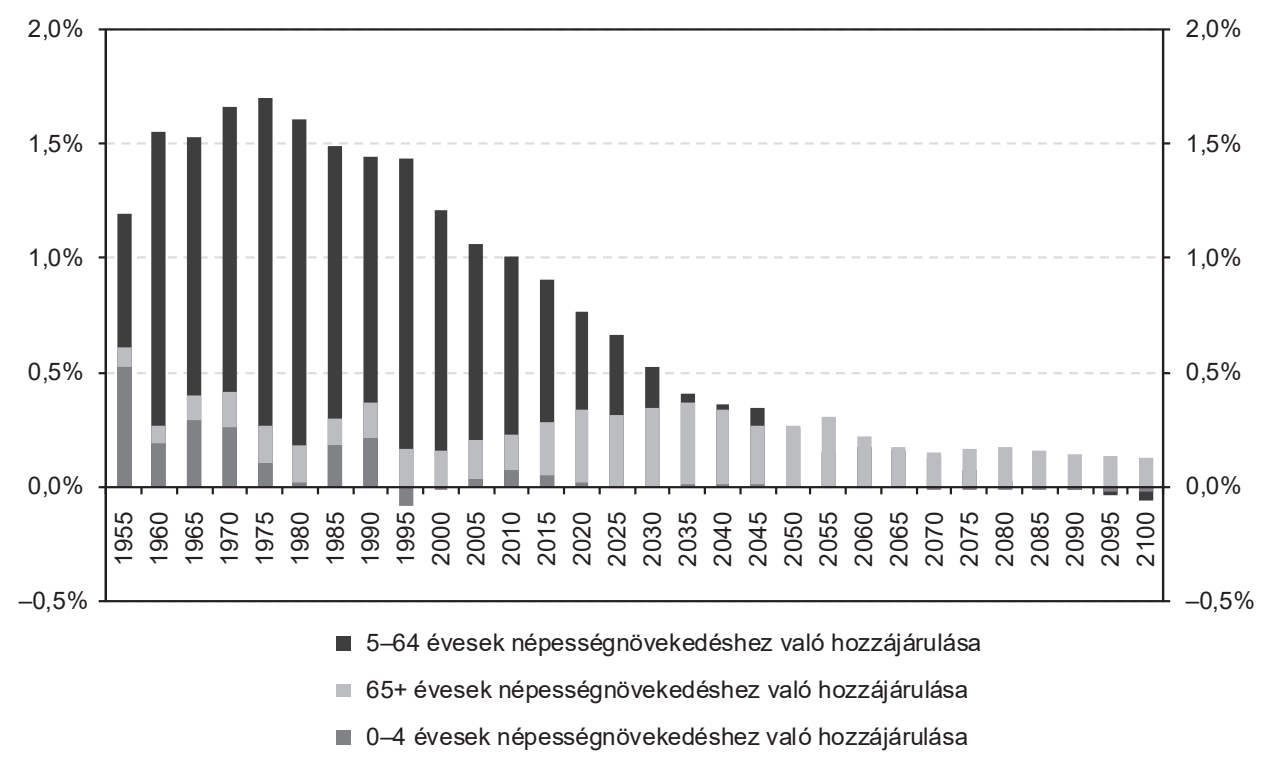

2. ábra

A 0-4, 5-64 és 65 évesnél idősebbek globális népességnövekedéshez való hozzájárulása az egyes években, $1955-2100$

Forrás: a szerző számítása a UN (2019) i. m. adatai alapján

\section{A koronavírus lehetséges demográfiai következményei}

A jövőbeli demográfiai folyamatra jelentősen hathat a koronavírus 2020-ban kezdődő nagyfokú terjedése és az ebből kibontakozó globális gazdasági válság is.

$\mathrm{Az}$ egyes országok jövőbeli demográfiai struktúráját jelentősen befolyásolhatja a járvány lefolyása, tartóssága. Már most több mint 1 millió ember halt meg globálisan, ${ }^{29}$ akiknek nagy része idős vagy krónikus beteg. ${ }^{30} \mathrm{Ez}$ egyelőre jelentősen elmarad a korábbi járványok halálozási számaitól, illetve az évi, globálisan közel 60 millió halálozástól. Azonban a járvány tartóssága, esetleges évenkénti visszatérése, ${ }^{31}$ vagy az elkövetkező években esetlegesen gyakoribb globális járványok ${ }^{32}$ lelassíthatják a várható élettartam és a mortalitási ráta javulását. Ez már idén is megtörténhet, hisz március közepétől április végéig a legtöbb európai országban közel 1,5-szer többen haltak meg, mint a sokéves

29 A halálesetek tényleges száma valószínúleg jelentősen nagyobb, hisz számos országban rendkívül alacsony a tesztelési kapacitás, az elvégzett tesztek száma.

Worldometer: Coronavirus. 2020c.

Bloomberg: Virus Likely to Keep Coming Back Each Year, Say Top Chinese Scientists, 2020.

Jon Hilsenrath: Global viral outbreaks like coronavirus, once rare, will become more common. The Wall Street Journal, 2020. 
átlag az Euromomo ${ }^{33}$ adatai alapján. ${ }^{34}$ Amennyiben a várható élettartam és a mortalitási ráták az elkövetkező években lassabban javulnak (extrém esetben romlanak), mint a UN 2019-es előrejelzése, az a globális népességnövekedést is lassíthatja. Korábban láthattuk, hogy a népességnövekedés okát egyre inkább minőségi tényezők határozzák meg, az idősebb korúak népességének növekedése egyre nagyobb mértékben járul hozzá a növekedéshez. A vírus így részben csökkentheti az időskorúak népességnövekedéshez való hozzájárulását, illetve az elöregedési problémákat is késleltetheti.

Emellett a védekezés kapcsán hozott karanténok, „social distancing” eljárások és gazdasági leállások jelentős gazdasági visszaeséshez vezettek az összes országban. Az IMF 2020-as prognózisa alapján idén globálisan 3\%-kal eshet vissza a globális gazdaság, amelyre az 1929-1932-es nagy válság óta nem volt példa. ${ }^{35}$ A gazdasági visszaesés érdemben befolyásolhatja az egyes országokban a teljes termékenységi arányszám alakulását. A 2007-2008-as gazdasági válság Európában és az Amerikai Egyesült Államokban is jelentősen csökkentette a nők gyermekvállalási hajlandóságát: többek között a női munkanélküliség növekedése, a fogyasztói bizalom csökkenése ${ }^{36}$ és a fogamzásgátló-használat növekedésén keresztül. ${ }^{37}$ Így várhatóan a fejlett országokban a koronavírus utóhatása lesz a csökkenő teljes termékenységi arányszám, amely Magyarország számára valószínúleg megnehezítheti - ha nem teljesen meghiúsítja - a 2030-ra kitűzött 2,1-es teljes termékenységi arányszám elérését. A fejlődő országokban várható hatások nehezebben megítélhetők, összességében az empirikus irodalom alapján kis jövedelemszint mellett a gazdaság növekedése a fertilitás csökkenéséhez vezet, ${ }^{38}$ azonban az ellentétes mozgást, gazdasági visszaesést viszonylag kevés tanulmány vizsgálta. Davalos és Morales tanulmányukban 1998 és 2013 közötti kolumbiai adatokon azt találták, hogy receszsziós időszakokban csökkent a szegényebb államokban a fertilitás. ${ }^{39}$ Ellenben Wright és szerzőtársai tanulmányukban azt találták, hogy Lagoszban a recessziós időszakokban csökken a fogamzásgátlók használata, ami a fertilitás növekedését eredményezheti. ${ }^{40}$

Euromomo: Graphs and maps. 2020.

Szerencsére Európában május közepétől ősz elejéig a halálesetek száma újra a trend környékén alakult. Gita Gopinath: The Great Lockdown: worst economic downturn since the Great Depression. IMF, 2020.

Chiara L. Comolli: The fertility response to the Great Recession in Europe and the United States: Structural economic conditions and perceived economic uncertainty. Demographic Research, 36. (2017), 51. 1549-1600.; Anna Matysiak - Tomáš Sobotka - Daniele Vignoli: The Great Recession and fertility in Europe: A sub-national analysis. Vienna Institute of Demography Working Papers, (2018), 2. 1-41. Daniel Schneider: Non-marital and teen fertility and contraception during the great recession. The Russell Sage Foundation Journal of the Social Sciences, 3. (2017), 3. 126-144.

Myrskylä-Kohler-Billari (2009) i. m.

39 Eleonora Davalos - Leonardo F. Morales: Economic crisis promotes fertility decline in poor areas: Evidence from Colombia. Demographic Research, 37. (2017), 27. 867-888.

$40 \quad$ Kikelomo O. Wright et alii: Economic recession and family planning uptake: Review of a Nigerian health institution. Tropical Journal of Obstetrics and Gynaecology, 35. (2018), 2. 147-152. 


\section{6. Összegzés}

Összességében megállapítható, hogy a világ népességének kétharmada már olyan országban lakik, ahol a teljes termékenységi arányszám alatta marad a reprodukciós szinthez tartozó fertilitási rátának. Globálisan egyre szűkül azon országok száma, ahol kvantitatív módon növekszik a népesség, vagyis a magas gyermekvállalás a növekedés meghatározója. Egyre több és több fejlődő ország népességnövekedése kvalitatív alapú, vagyis a javuló mortalitás a növekedés mozgatórugója. Emiatt a ma még csak a fejlett országok problémájának tûnő elöregedés problematikája fokozatosan teret nyerhet a fejlődő országok között is, ahol jóval kisebb egy főre jutó jövedelem mellett kell majd megküzdeni az eltartottak és időskorúak növekvő számával. Egyes fekete-afrikai országokban továbbra is magas a gyermekvállalás, ezen országok helyzete a túlnépesedés szóval is illethető, azonban ennek a kiterjesztése az egész fejlődő világra túlzónak tekinthető, hisz számos fejlődő országban inkább a csökkenő népesség elöregedéssel és a szűkülő munkaerőpiaccal karöltve okozhat problémát. A gyermekvállalási hajlandóságot a jólét növekedésével párhuzamosan a szülők számára megjelenő növekvő költségek és elapadó nyereségek is csökkentik: tisztán közgazdaságtani megközelítésből egy fejlett országban egy gyermek huszonéves koráig a szülők számára jelentős költséget jelent, szemben a megelőző korokkal, mikor az életben maradó gyermek nagyon hamar, élőmunkáján keresztül anyagilag is hozzájárult a szülők boldogulásához. A koronavírus okozta halálesetek, illetve az azzal párhuzamosan bekövetkező gazdasági válság miatti alacsonyabb gyermekvállalási szándék még inkább csökkenthetik a globális népességnövekedés dinamikáját, a túlnépesedés helyett egyre inkább az elöregedés kerülhet középpontba mint globális probléma.

\section{Mellékletek}

1950

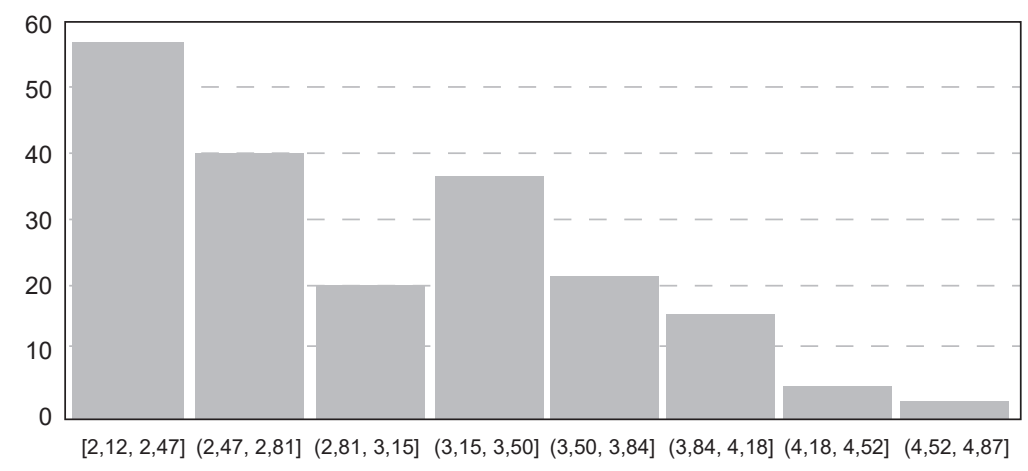

Európai Tükör 2020/4. 
1980

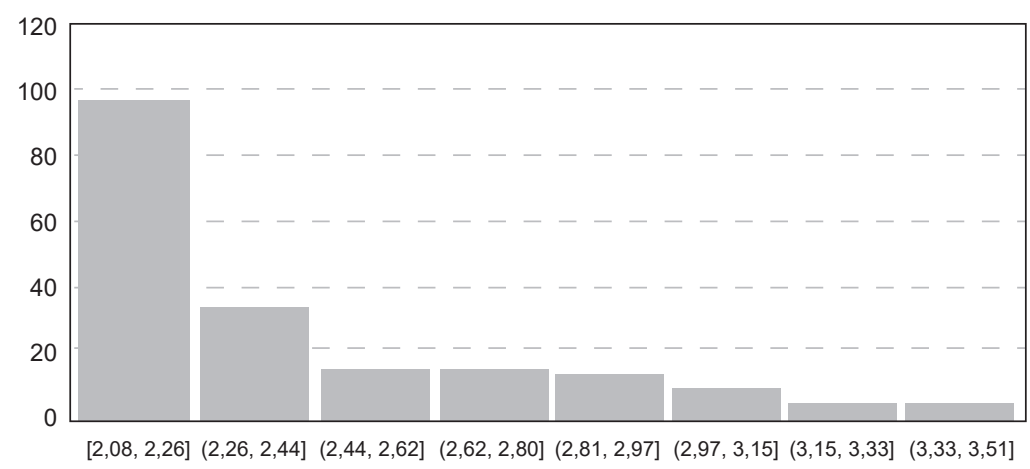

2015

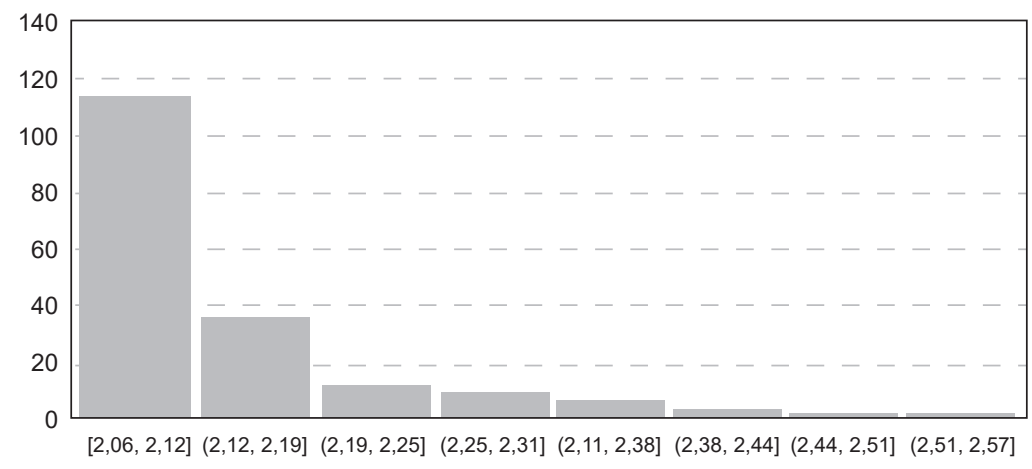

2040

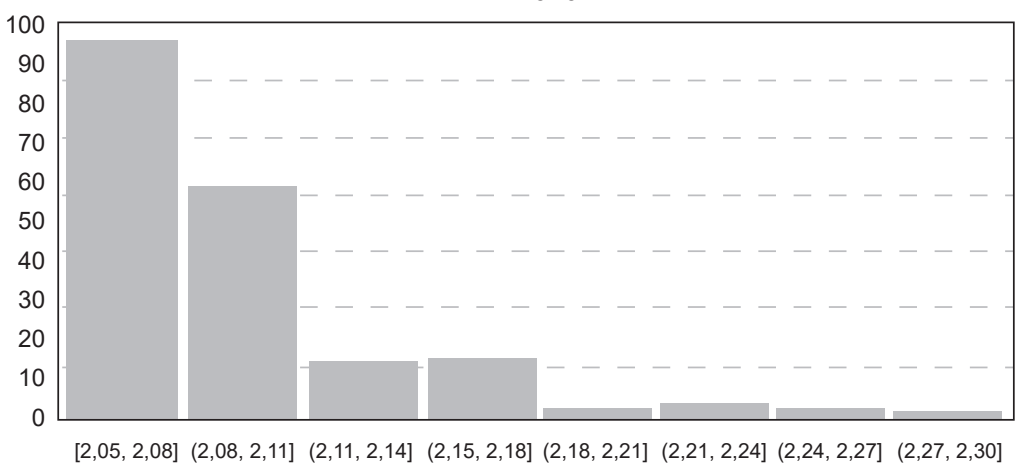

A.1. ábra

A reprodukciós szinthez tartozó fertilitási ráta hisztogramjai 1950-re, 1980-ra, 2015-re és 2040-re vonatkozóan

Forrás: a szerző számítása a UN (2019) i. m. és Világbank (2019) i. m. adatai alapján 


\section{A.2. táblázat}

A demográfiai ablak idôintervalluma a világ öt legnagyobb népességü országában, a világon, illetve Magyarország esetében

\begin{tabular}{|c|c|c|c|}
\hline & $\begin{array}{c}\text { Demográfiai ablak } \\
\text { kezdete }\end{array}$ & $\begin{array}{c}\text { Demográfiai ablak } \\
\text { vége }\end{array}$ & $\begin{array}{c}\text { Demográfiai ablak } \\
\text { hossza }\end{array}$ \\
\hline Magyarország & 1950 előtt & 2000 & - \\
\hline Világ & 2000 & 2045 & 45 \\
\hline Kína & 1985 & 2025 & 40 \\
\hline India & 2010 & 2055 & 45 \\
\hline USA & 1965 & 2020 & 55 \\
\hline Indonézia & 2005 & 2045 & 40 \\
\hline Pakisztán & 2035 & 2085 & 50 \\
\hline
\end{tabular}

Forrás: a szerző szerkesztése a UN (2019) i. m. alapján

\section{Felhasznált irodalom}

Bleha, Branislav - Branislav Šprocha - Boris Vaňo - Erzsébet Földházi: Population projections for Hungary and Slovakia at national, regional and local levels. Population projections developed within the project 'SEEMIG Managing Migration and Its Effects

Bloomberg: Virus Likely to Keep Coming Back Each Year, Say Top Chinese Scientists, 2020. Online: www.bloomberg.com/news/articles/2020-04-28/virus-is-here-tostay-and-likely-seasonal-say-china-scientists

Buck, Nick - Jacqueline Scott: Household and family change. In Nick Buck - Jonathan Gershuny - David Rose - Jacqueline Scott: Changing Households: The British Household Panel Survey 1990-1992. University of Essex, ESRC Centre on Micro-Social Change, 1994. 61-82.

Cherlin, Andrew J.: Marriage, Divorce, Remarriage. Cambridge, Harvard University Press, 1992.

Comolli, Chiara L.: The fertility response to the Great Recession in Europe and the United States: Structural economic conditions and perceived economic uncertainty. Demographic Research, 36. (2017), 51. 1549-1600. Online: https://doi.org/10.4054/ demres.2017.36.51

Crenshaw, Edward M. - Ansari Z. Ameen - Matthew Christenson: Population dynamics and economic development: Age-specific population growth rates and economic growth in developing countries, 1965 to 1990. American Sociological Review, 62. (1997), 6. 974-984. Online: https://doi.org/10.2307/2657351

Davalos, Eleonora E. - Leonardo F. Morales: Economic crisis promotes fertility decline in poor areas: Evidence from Colombia. Demographic Research, 37. (2017), 27. 867888. Online: https://doi.org/10.4054/DemRes.2017.37.27

Davis, Kingsley: Low fertility in evolutionary perspective. Population and Development Review, 12. (1986), 48-65. Online: https://doi.org/10.2307/2807892

Európai Tükör 2020/4. 
Espenshade, Thomas J. - Juan C. Guzman - Charles F. Westoff: The surprising global variation in replacement fertility. Population Research and Policy Review, 22. (2003), 5-6. 575-583. Online: https://doi.org/10.1023/B:POPU.0000020882.29684.8e,

Euromomo: Graphs and maps. Online: www.euromomo.eu/graphs-and-maps

Furstenberg, Frank F.: Family change and the welfare of children: What do we know and what can we do about? In Karen Oppenheim Mason - An-Magritt Jensen (szerk.): Gender and Family Change in Industrialised Countries. Oxford, Clarendon Press, 1995. 245-257.

Gietel-Basten, Stuart - Sergei Scherbov: Exploring the 'True Value' of Replacement Rate Fertility. Population Research and Policy Review, 39. (2019), 763-772. Online: https:// doi.org/10.1007/s11113-019-09561-y

Hilsenrath, Jon: Global viral outbreaks like coronavirus, once rare, will become more common. The Wall Street Journal, 2020. Online: www.wsj.com/articles/viral-outbreaks-once-rare-become-part-of-the-global-landscape-11583455309

Gopinath, Gita: The Great Lockdown: worst economic downturn since the Great Depression, IMF, 2020. Online: blogs.imf.org/2020/04/14/the-great-lockdown-worst-economic-downturn-since-the-great-depression/

kormany.hu: Orbán Viktor beszéde a Magyar Diaszpóra Tanács VIII. ülésén, 2018. Online: 2015-2019.kormany.hu/hu/a-miniszterelnok/hirek/2030-ra-magyarorszag-tartozzon-az-eu-5-legjobb-orszaga-koze

KSH Népességtudományi Kutatóintézet: Teljes termékenységi arányszám szócikk. Online: https://demografia.hu/hu/tudastar/fogalomtar/38-teljes-termekenysegi-aranyszam

Li, Hongbin - Junjian Yi - Junsen Zhang: Estimating the effect of the one-child policy on the sex ratio imbalance in China: Identification based on the difference-in-differences. Demography, 48. (2011), 4. 1535-1557. Online: https://doi.org/10.1007/ s13524-011-0055-y

Matysiak, Anna - Tomáš Sobotka - Daniele Vignoli: The Great Recession and fertility in Europe: A sub-national analysis. Vienna Institute of Demography Working Papers, (2018), 2. 1-41.

Myrskylä, Mikko - Hans-Peter Kohler - Francesco C. Billari: Advances in development reverse fertility declines. Nature, 460. (2009), 7256. 741-743. Online: https://doi. org/10.1038/nature08230

Obádovics Csilla: A népesség szerkezete és jövője. In Monostori Judit - Őri Péter - Spéder Zsolt (szerk.): Demográfiai Portré 2018. Budapest, KSH Népességtudományi Kutatóintézet, 2018. 271-294.

Pimentel, David: World overpopulation. Environment, Development and Sustainability, 14. (2012), 2. 151-152. Online: https://doi.org/10.1007/s10668-011-9336-2

Rosenfeld, Rachel A. - Gunn E. Birkelund: Women's part-time work: A cross-national comparison. European Sociological Review, 11. (1995), 2. 111-134. Online: https:// doi.org/10.1093/oxfordjournals.esr.a036352

Schlumbohm, Jürgen: Traditional collectivity and modern individuality: Some questions and suggestions for the historical study of socialization: The examples of the German lower and upper bourgeoisie around 1800. Social History, 5. (1980), 1. 71-103. Online: https://doi.org/10.1080/03071028008567471 
Schneider, Daniel: Non-marital and teen fertility and contraception during the great recession. The Russell Sage Foundation Journal of the Social Sciences, 3. (2017), 3. 126144. Online: https://doi.org/10.7758/RSF.2017.3.3.06

Shivani, Uniyal - Rashmi Paliwal - Bhumija Kaphaliya - R. K. Sharma: Human overpopulation: Impact on environment. In Megacities and Rapid Urbanization. Information Resources Management Association, 2020. 20-30. Online: https://doi. org/10.4018/978-1-5225-9276-1.ch002

Smallwood, Steve - Jessica Chamberlain: Replacement fertility, what has it been and what does it mean? Population Trends, (2005), 119. 16-27.

Stone, Lawrence: The Family, Sex and Marriage in England 1500-1800. New York, Harper and Row, 1977.

Transnational Actions Towards Evidence Based Strategies', 2014. Online: www.seemig. eu/downloads/outputs/SEEMIGPopulationProjectionsHUSK.pdf

Tsui, Ong - Amy Bogue - Donald J. Bogue: Declining world fertility: trends, causes, implications. Population Bulletin, 33. (1978), 4. 2-56.

UN: World Population Prospects. 2019. Online: https://population.un.org/wpp/

Világbank: 2019. Online: https://data.worldbank.org/

Vollset, Stein - Emily Goren - Chun-Wei Yuan - Jackie Cao - Amanda E. Smith - Thomas Siao et alii: Fertility, mortality, migration, and population scenarios for 195 countries and territories from 2017 to 2100: a forecasting analysis for the Global Burden of Disease Study. The Lancet, 396. (2020), 10258. 1285-1306. Online: https://doi. org/10.1016/S0140-6736(20)30677-2

Westoff, Charles F.: Reproductive Intentions and Fertility Rates. International Family Planning Perspectives, 16. (1990) 3. 84-89 + 96. Online: https://doi.org/10.2307/2133304

Worldometer: World Population by Year. 2020a. Online: www.worldometers.info/world-population/world-population-by-year/

Worldometer: World Population Projections. 2020b. Online: www.worldometers.info/world-population/world-population-projections/

Worldometer: Coronavirus. 2020c. Online: www.worldometers.info/coronavirus/?fbclid= IwAR17P1QkME3Aa4A9bq4gSc1kXIg06aNq5PSUPN-Q2pHVn6Jjo KCKXO0gcMk

Wright, Kikelomo O. - E. Ukatu - T. A. Ottun - M. O. Oyebode - V. Sarma - S. Chung: Economic recession and family planning uptake: Review of a Nigerian health institution. Tropical Journal of Obstetrics and Gynaecology, 35. (2018), 2. 147-152. Online: https://doi.org/10.4103/TJOG.TJOG_82_17

Európai Tükör 2020/4. 